\title{
Investigation of fracture of carbon steel springs used for furniture application
}

\author{
R. Kandrotaitė Janutienè \\ Kaunas University of Technology, Studentu str. 56-323, 51424 Kaunas, Lithuania, E-mail: raskand@ktu.lt \\ cross $^{\text {ref }}$ http://dx.doi.org/10.5755/j01.mech.22.5.15434
}

\section{Introduction}

The high strength springs usually are produced from hypereutectoid steel wires containing 0.7-0.9\% carbon [1-5]. The higher content of carbon is, the better mechanical properties can be achieved. Hypereutectoid steel wires have very fine pearlitic microstructure that is obtained by a special heat treatment process called patenting $[5,6]$. Patenting is a phase transformation process, which involves heating of wires up to austenitic temperature followed by sudden quenching usually in bath of lead or molten salts that maintains stable temperature. After such heat treatment the wires are turned to cold drawing on purpose to obtain the maximum strength. Severe plastic deformation leads not only to high strength of material but also to big stresses and low tensile strength. Seeking to decrease the remained stresses and to increase elasticity and relaxation resistance of material, the coiled springs are tempered at $200-300{ }^{\circ} \mathrm{C}$ temperature. After tempering elasticity limit increases $100 \%$ comparing with not tempered spring and tensile strength increases just $10 \%$. Relaxation resistance of tempered springs is improved 2-3 times, fatigue limit - 5$10 \%[1]$.

The quality of spring can be normally taken into consideration in such cases as:

i. a spring installed in final products, failed either by fracture or by significant deformation in use;

ii. newly designed or improved product requires a new design of a spring thus the selection of the material;

iii. cost reduction for the spring used is requested without any difference of the quality [7].

The case of fracture of spring (i) can be divided into the following several cases:

- volume defects, these can be defined as non-metallic inclusions directly related with material quality $[8,9]$;

- surface defects as high roughness, decarburization because of heat treatment, scratches, cracks, corrosion affected areas, etc. Usually these mentioned defects are monitored according requirements of standard documents [10-12].

When a spring has failed due to any case, an investigation for finding the failure cause should be carried out, and the quality of the material should be used and the manufacturing process history are required to be studied.

As described above, the most suitable selection of spring material and its working processes should be chosen as it plays a very important role in quality and cost.

The main aim of the work was to specify the reasons of fracture of springs used in furniture production as the manufacturer has declared that these springs did not meet the desirable properties and to propose the recommendations for their production.

\section{Material and methodology}

Material used for the experimentation was carbon spring steel wire with the diameter of $3.8 \mathrm{~mm}$. Its chemical composition listed in Table 1 and mechanical properties are presented in Table 2.

Table 1

Chemical composition of spring steel wire according certification of producer No. 10050/15, 201511

\begin{tabular}{|c|c|c|c|c|c|c|c|}
\hline \multicolumn{7}{|c|}{ Element, wt.\% } \\
\hline $\mathrm{C}$ & $\mathrm{Mn}$ & $\mathrm{Si}$ & $\mathrm{P}$ & $\mathrm{S}$ & $\mathrm{Cr}$ & $\mathrm{Ni}$ & $\mathrm{Fe}$ \\
\hline 0.81 & 0.650 & 0.200 & 0.013 & 0.012 & 0.040 & 0.030 & Rem \\
\hline
\end{tabular}

Table 2

Mechanical properties of spring steel wire according certification of producer No. 10050/15 and 10988/15, 2015

11

\begin{tabular}{|c|c|c|c|}
\hline$d_{\min }, \mathrm{mm}$ & $d_{\max }, \mathrm{mm}$ & $R_{m(\min )}, \mathrm{MPa}$ & $\begin{array}{c}R_{\operatorname{m}(\max )}, \\
\mathrm{MPa}\end{array}$ \\
\hline \multicolumn{4}{|c|}{ Specified } \\
\hline 3.77 & 3.83 & 1650 & 1850 \\
\hline \multicolumn{4}{|c|}{ Tested (No.1) } \\
\hline 3.806 & 3.822 & 1694 & 1751 \\
\hline \multicolumn{4}{|c|}{ Tested (No. 2) } \\
\hline 3.801 & 3.827 & 1694 & 1756 \\
\hline
\end{tabular}

The steel wire rods were phosphate in $\mathrm{KOCH}$ on purpose to increase corrosion resistance.

The mentioned wire was used for coiling the zigzag springs which were tempered in a big industrial furnace $(60 \mathrm{~kW})$ with forced air mixing (two fans installed in the top wall of the furnace). The regime of tempering was heating up to $300{ }^{\circ} \mathrm{C}$ within $180 \mathrm{~min}$ and leaving at this temperature for $45 \mathrm{~min}$. After such treatment the springs were tested applying a dynamic load with a $75 \mathrm{~kg}$ free fall drop weight. After 5965 cycles the test was stopped because of spring fracture. It did not satisfy the requirements of 15000 cycles acting $1500 \mathrm{~N}$ force.

Two groups of tests were made analysing the reasons of spring fractures:

- examining the material quality by observing steel microstructure, and

- testing the mechanical properties of steel by tensile test.

The microstructure of steel was examined by optical microscope Nikon with objective Nikon TU Plan Fluor 100x/0.90 and video camera Nikon DS-R:2 $16 \mathrm{MP}$. The samples for optical analysis were cut from the random places in transverse and longitudinal directions, then were ground, polished by Lam Plan machine using diamond suspension of $1 \mu \mathrm{m}$ grain size, and finally etched in $3 \%$ Nital solution. 
Rockwell hardness of spring steel was examined by Universal hardness meter VERZUS 750CCD. For the purpose to eliminate the possible error of hardness measurement concerning cylindrical shape of wire, the surface of tested piece was ground approximately $0.5 \mathrm{~mm}$ from the both sides to make it flat (Fig. 1).

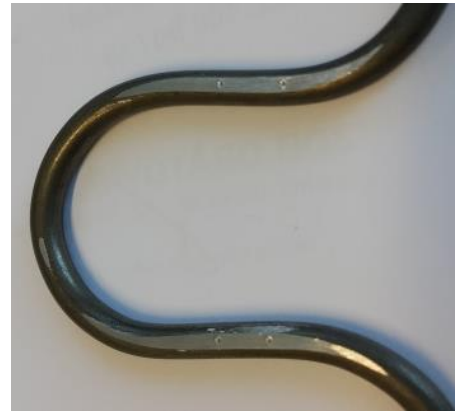

Fig. 1 Prepared surface of specimen for hardness measurement

For the purpose to obtain mechanical properties such as tensile strength and yield point the axial tension tests were run on the universal hydraulic $5 \mathrm{t}$ tension-compression testing machine, which applied the axial load through flat end platens without any additional fixing. The loading rate was set as $10 \mathrm{~mm} / \mathrm{min}$ for all time so that quasi-static response could be obtained. Experimental additional equipment consisted of: force transducer and displacement transducer with the measurement ranges $10 \mathrm{kN} \pm 10 \mathrm{~N}$ and $50 \pm 0.1 \mathrm{~mm}$, respectively. Tensile specimen is presented in Fig. 2.

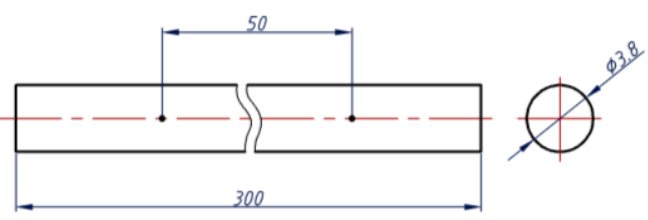

Fig. 2 Wire specimen for tensile test with gauge length of $50 \mathrm{~mm}$

As the industrial heating furnace was designed with the thermocouple installed in the wall near the control system block and two big pallets of springs were heated during one tempering process, test for examining of reached temperature of wire springs was performed. 18 rods of wire (group A) were arranged into the pallets according scheme presented in Fig. 3 and tempered in the industrial furnace. Before tempering, the black coating of phosphates was removed from the surface of specimens. During tempering the surface of cleaned specimens covered with different thickness of oxides that gave different colour.

The same was made with specimens (group B) with welded chromel-alumel thermocouples of thickness $0.3 \mathrm{~mm}$ tempered in the laboratory furnace at different temperature and for different duration (Fig. 4). The tempering regimes are presented in Table 3. Tempering regimes (temperature and duration) were chosen according most recommended in different scientific works [1-5].

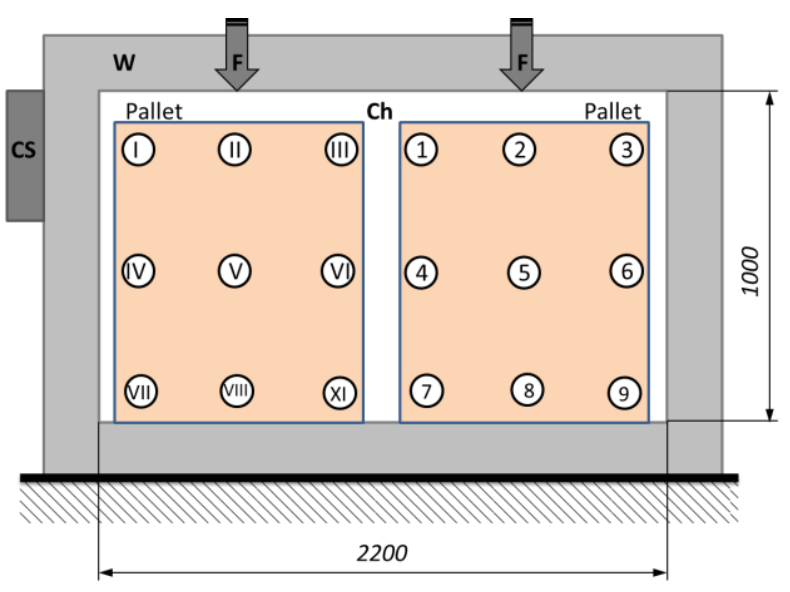

Fig. 3 Schematic front view of arrangement of wire rods as specimens inside pallets of springs placed into the chamber of furnace. Arbitrary signs: CS - control system; W - furnace wall containing 24 heating elements; $\mathrm{F}$ - fan; $\mathrm{Ch}$ - furnace chamber

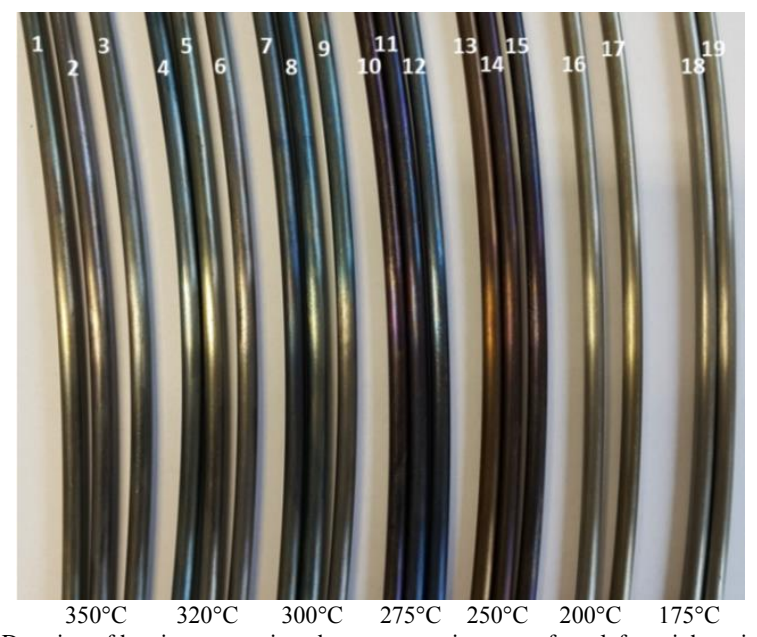

Duration of heating at mentioned temperature increases from left to right, min

Fig. 4 Variation in oxide film colour of specimens of group $\mathrm{B}$ tempered in laboratory furnace. Colour of oxide film: $350^{\circ} \mathrm{C}-$ yellowish with grey shade; $320^{\circ} \mathrm{C}-$ yellowish with slight bluish shade; $300{ }^{\circ} \mathrm{C}-$ yellowish with intense blue shade; $275^{\circ} \mathrm{C}-$ intermediate of purple and blue; $250^{\circ} \mathrm{C}$ - intense brown; $200^{\circ} \mathrm{C}$ - intense yellow; $175^{\circ} \mathrm{C}$ - yellow

Table 3

Tempering temperatures and duration of specimens heated in laboratory furnace (group B)

\begin{tabular}{|c|c|c|c|}
\hline $\begin{array}{c}\text { Tempering } \\
\text { temperature, }{ }^{\circ} \mathrm{C}\end{array}$ & \multicolumn{3}{|c|}{$\begin{array}{c}\text { Specimen No. corresponds duration of } \\
\text { heating, min }\end{array}$} \\
\hline \multirow{2}{*}{350} & No.1 & No. 2 & No.3 \\
\hline & 10 & 20 & 30 \\
\hline \multirow{2}{*}{320} & No.4 & No.5 & No.6 \\
\hline & 15 & 30 & 45 \\
\hline \multirow{2}{*}{300} & No.7 & No.8 & No.9 \\
\hline & 20 & 30 & 60 \\
\hline \multirow{2}{*}{275} & No. 10 & No.11 & No.12 \\
\hline & 20 & 30 & 60 \\
\hline \multirow{2}{*}{250} & No.13 & No.14 & No. 15 \\
\hline & 30 & 60 & 90 \\
\hline \multirow{2}{*}{200} & No.16 & No.17 & \\
\hline & 90 & 120 & \\
\hline \multirow{2}{*}{175} & No.18 & No.19 & \\
\hline & 90 & 120 & \\
\hline
\end{tabular}


After tempering the colour of specimens of group B was compared with specimens of group A. Such simple method allowed determining the approximate temperature in different places of the industrial furnace chamber.

\section{Results and discussion}

3.1. Analysis of microstructure and defects of material of broken spring steel wires

Twelve longitudinal and transverse samples for microscopy analysis were cut from random places of tempered springs that were broken during free fall drop test. When the samples were prepared, at first not etched surface was observed for the evaluation of non-metallic inclusions. Oxides, sulphides, silicates and other non-metallic inclusions found at the surface of spring may initiate a crack with following fracture. The documents EN 10270-1 and EN 10016 specify that non-metallic inclusions should be examined just on the request of customer [10-12].

Polished and not etched surface of the samples showed very few and small oxides just several micrometres in size (Fig. 5) that could not be a reason of fracture of springs. Oxides could be classed to index $i=0.5$ (the lowest index for globular oxides) according standard ISO 4967:2013 [13].

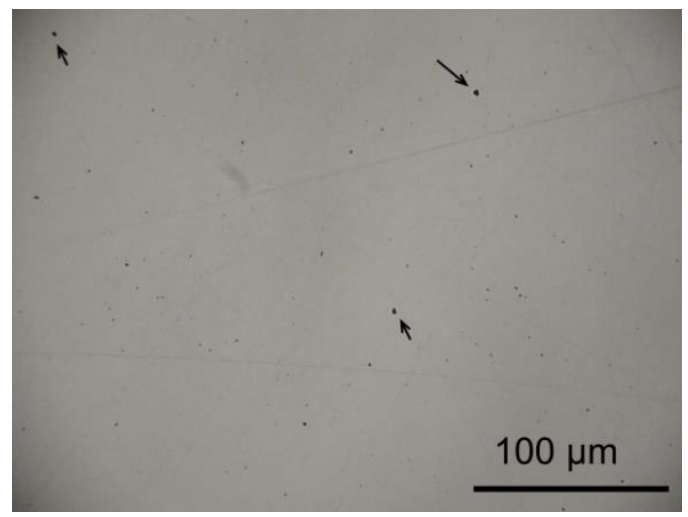

Fig. 5 Non-metallic inclusions found in spring steel. The biggest ones are shown by arrows

Etching of the surface of samples revealed the fibrous microstructure in longitudinal cross-section and fine microstructure in transverse direction (Fig. 6). The hardness was determined to be 46-48 HRC corresponding with the data ( 46.9 HRC) found in literature [14]. Several scientific articles have identified the microstructure as fine pearlite (sorbite) [5, 15-17], also, some traces of bainite may exist $[5,18]$. Precise examination of microstructure of steel wire requires other investigation techniques such as X-ray analysis or micro-indentation [5, 19].

For examination of decarburization all transverse samples were observed. According standard EN 10270-1 [10], permissible depth of decarburization for the wire with $3.8 \mathrm{~mm}$ diameter should not exceed $1.5 \%$ of diameter $(57 \mu \mathrm{m})$. Among six transverse samples just one showed the signs of decarburization (Fig. 7). It could be identified as brighter strip with thickness of 30-40 $\mu \mathrm{m}$ near the surface of sample. The found decarburization did not exceed the permissible limits mentioned in standard EN 10270-1 but in spite of that it showed facilitated conditions of crack initiation and propagation, thus the fatigue resistance may be decreased in some places of spring [20].

Besides decarburization small surface roughness also can be seen in Fig. 7. Roughness of wire surface can be a cause of crack propagation, too.

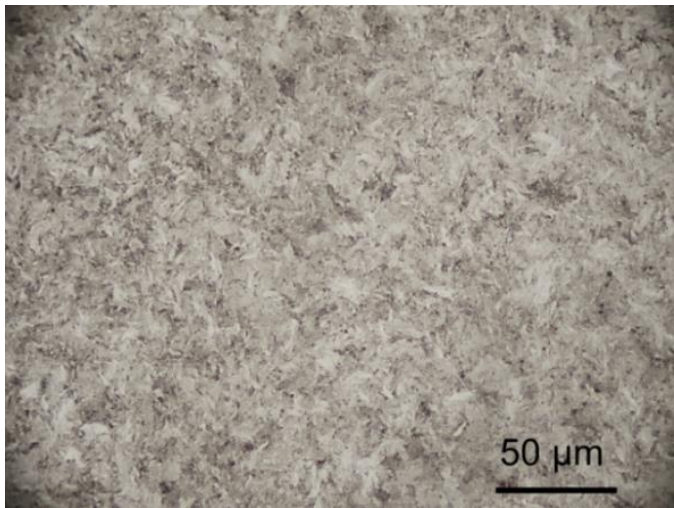

a

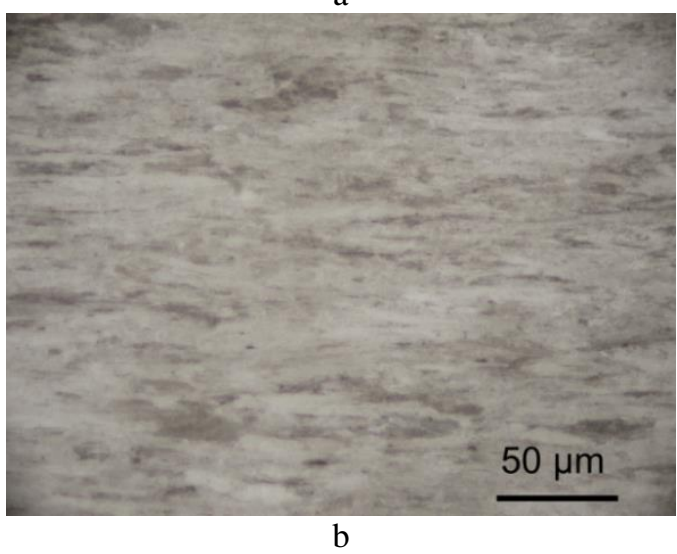

Fig. 6 Microstructure of patented and tempered hypereutectoid steel wire: a) transverse section, b) longitudinal section

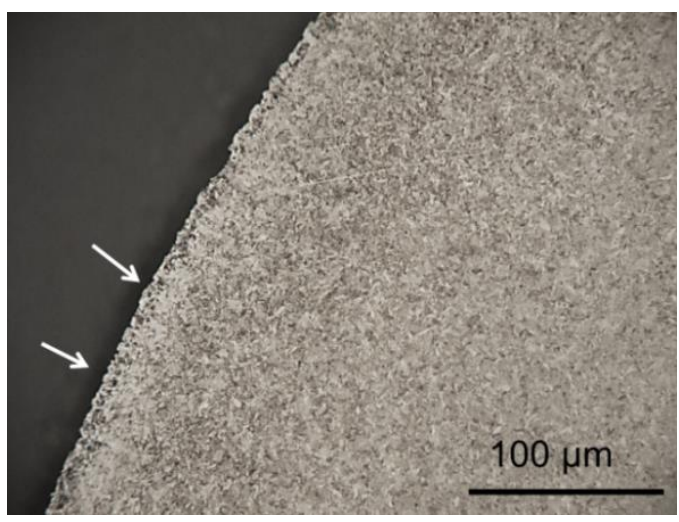

Fig. 7 Decarburized surface of patented and tempered steel wire

3.2. Investigation of industrial heat treatment process of springs

After tempering of the specimens of group A (industrial furnace), the specimens were compared with the ones of group B and very approximate tempering temperature was determined for the specimens of group A. The colour of oxide film of the specimens of group A showed that during heating in industrial furnace (with set parameters $T=300{ }^{\circ} \mathrm{C}, t=45 \mathrm{~min}$ ) the springs could reach 
moderately $220-240{ }^{\circ} \mathrm{C}$ temperature as their colour was obtained yellow just several of them that were arranged at the right side of the furnace chamber (specimens No. 3, 6 and 9, Fig. 3) have reached $280-300{ }^{\circ} \mathrm{C}$.

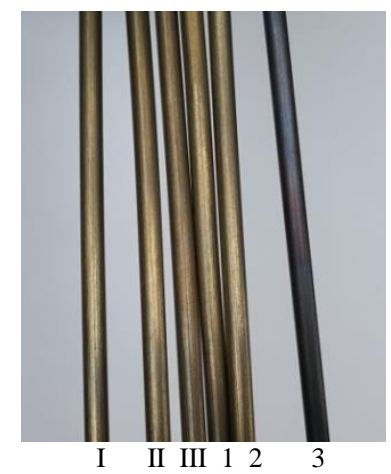

a
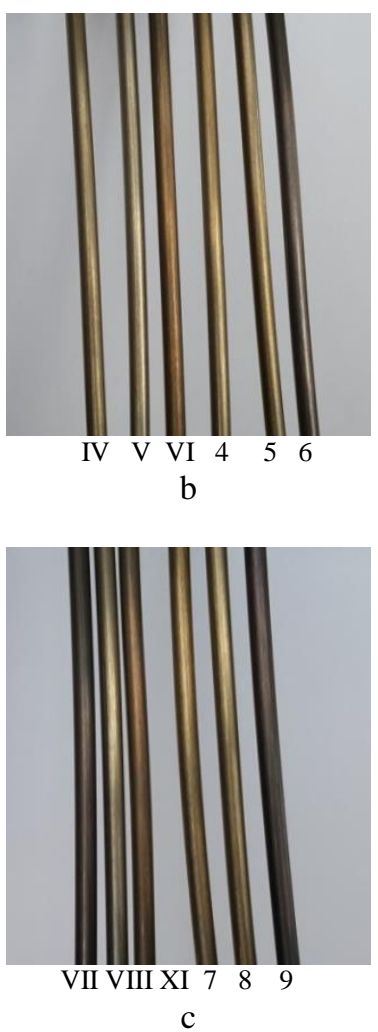

Fig. 8 Variation of oxide film colour of specimens of steel wires tempered in industrial furnace at set temperature $300{ }^{\circ} \mathrm{C}$ for $45 \mathrm{~min}$ (group A). Numbers below pictures show specimens' numbering according arrangement scheme in furnace (Fig. 3). Approximate colours: a - I, II, 1 and 2 were intense yellow; III was yellow with brown shade; 3 was blue; b - IV, V, 4 and 5 were yellow with different intensity, VI was slight brown; 6 was blue with brown shade; c - VII was brown with blue shade; VIII was intense yellow; XI was intense brown; 7 and 8 were yellow with brown shade; 9 was blue

The specimens of group A tempered in industrial furnace at $300{ }^{\circ} \mathrm{C}$ for $45 \mathrm{~min}$ are presented in Fig. 8. Their numbering is shown in Fig. 3. The comparison of colours of oxide films between specimens tempered in industrial furnace and laboratory one are listed in Table 4 and the map of temperatures inside spring pallets during heating is imagined in Fig. 9.

Table 4

Approximate temperature that was reached by specimens of group A during tempering in industrial furnace

\begin{tabular}{|c|c|c|c|c|c|c|}
\hline \multirow{2}{*}{$\begin{array}{c}\text { Position } \\
\text { in furnace }\end{array}$} & \multicolumn{3}{|c|}{ Identified temperature of specimens, ${ }^{\circ} \mathrm{C}$} \\
\cline { 2 - 7 } & \multicolumn{3}{|c|}{ Left pallet } & \multicolumn{3}{c|}{ Right pallet } \\
\hline \multirow{2}{*}{ Upper } & I & II & III & 1 & 2 & 3 \\
\cline { 2 - 7 } specimens & $200-$ & $200-$ & $230-$ & $200-$ & $200-$ & 300 \\
& 220 & 220 & 240 & 220 & 220 & \\
\hline \multirow{2}{*}{ Middle } & IV & V & VI & 4 & 5 & 6 \\
\cline { 2 - 7 } specimens & $220-$ & 200 & $200-$ & $210-$ & $210-$ & 300 \\
& 230 & & 220 & 220 & 220 & \\
\hline \multirow{2}{*}{ Bottom } & VII & VIII & XI & 7 & 8 & 9 \\
\cline { 2 - 7 } specimens & $230-$ & $200-$ & $200-$ & $210-$ & $280-$ & 300 \\
& 240 & 220 & 220 & 220 & 290 & \\
\hline
\end{tabular}

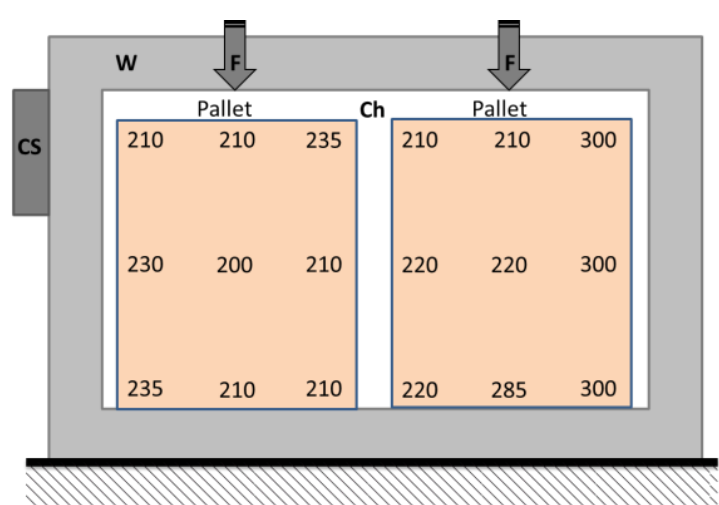

Fig. 9 Map of reached temperatures of different places of spring pallets during heating at $300{ }^{\circ} \mathrm{C}$

Lower temperatures than expected showed that the springs arranged in pallets did not reach the set temperature, too. So, for the further evaluation of quality of springs the tensile test of specimens of both groups A and B was performed.

\subsection{Investigation of mechanical properties of spring steel wires}

The tensile properties obtained from the measured stress-strain curve shown in Fig. 10, were an ultimate strength and an offset $0.2 \%$ yield strength.

For the specimens of group A the ultimate strength was identified being 1875-1891 MPa for tempered springs and $1775 \mathrm{MPa}$ for not tempered. Standard EN 10270-1 specifies ultimate strength in the range of 1750-1950 MPa for the wire diameter $3.8 \mathrm{~mm}$ for high dynamic application [10]. The yield strength or elasticity limit is not specified but exactly these characteristics play important role on the resistance of springs $[3,21]$. It was mentioned that, e. g., the yield strength should be at least $88-89 \%$ of ultimate strength. Higher yield strength (90-95 \% of $R_{m}$ ) causes better resistance to relaxation and plastic deformation of springs.

Tensile test was performed for specimens of group B. The results of tensile test are listed in Table 5. The lowest strength was obtained for steel wire specimen tempered at $300{ }^{\circ} \mathrm{C}$ for $60 \mathrm{~min}$ (Fig. 11). This may be caused by tempering embrittlement at this temperature [7]. 


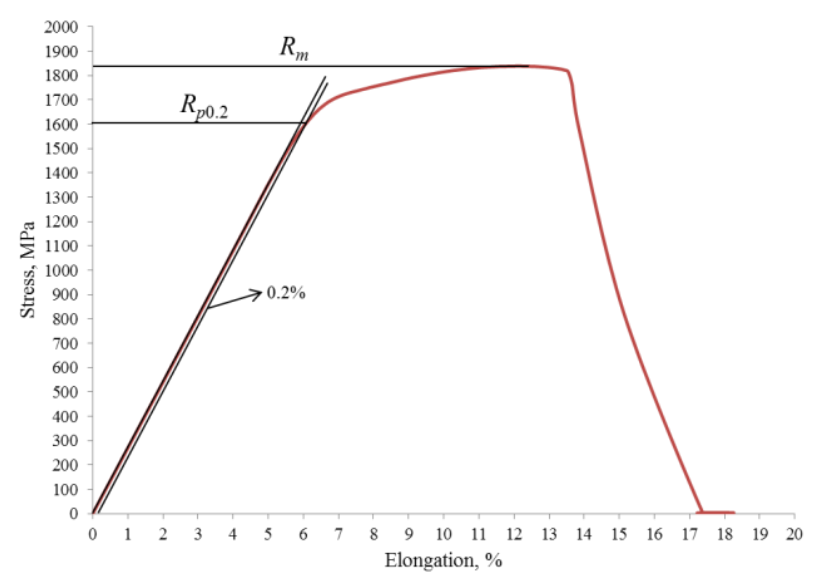

Fig. 10 Experimentally obtained engineering stress-strain curve for $3.8 \mathrm{~mm}$ diameter steel wire tempered at $320^{\circ} \mathrm{C}$ for $45 \mathrm{~min}$ (specimen of group B)

Table 5

Mechanical properties of steel wires tempered at different temperatures heating for various durations

\begin{tabular}{|c|c|c|c|c|c|c|}
\hline $\begin{array}{c}\text { Specimen } \\
\text { No.* }\end{array}$ & \multicolumn{4}{|c|}{ Mechanical properties } & \multicolumn{2}{c|}{$\begin{array}{c}\text { Tempering } \\
\text { regime }\end{array}$} \\
\cline { 2 - 8 } & $\begin{array}{c}R_{p 0.2,}, \\
\mathrm{MPa}\end{array}$ & $\begin{array}{c}R_{m}, \\
\mathrm{MPa}\end{array}$ & $\begin{array}{c}A, \\
\%\end{array}$ & $\begin{array}{c}\left(R_{p 0.2} / R_{m}\right) \times 100, \\
\%\end{array}$ & $T,{ }^{\circ} \mathrm{C}$ & $\begin{array}{c}t, \\
\text { min }\end{array}$ \\
\hline 1 & 1630 & 1831 & 18 & 89 & 350 & 10 \\
\hline 2 & 1530 & 1797 & 19 & 85 & 350 & 20 \\
\hline 3 & 1475 & 1801 & 18 & 82 & 350 & 30 \\
\hline 4 & 1575 & 1826 & 17 & 86 & 320 & 15 \\
\hline 5 & 1575 & 1826 & 17 & 86 & 320 & 30 \\
\hline 6 & 1580 & 1833 & 18 & 86 & 320 & 45 \\
\hline 7 & 1630 & 1839 & 18 & 89 & 300 & 20 \\
\hline 8 & 1625 & 1847 & 18 & 88 & 300 & 30 \\
\hline 9 & 1525 & 1820 & 20 & 84 & 300 & 60 \\
\hline 10 & 1680 & 1846 & 17.5 & 91 & 275 & 20 \\
\hline 11 & 1675 & 1855 & 15 & 90 & 275 & 30 \\
\hline 12 & 1680 & 1854 & 16 & 91 & 275 & 60 \\
\hline 13 & 1720 & 1875 & 16.5 & 92 & 250 & 30 \\
\hline 14 & 1680 & 1873 & 16 & 90 & 250 & 60 \\
\hline 15 & 1680 & 1858 & 16.5 & 90 & 250 & 90 \\
\hline 16 & 1650 & 1872 & 14 & 88 & 200 & 90 \\
\hline 17 & 1680 & 1891 & 14.5 & 89 & 200 & 120 \\
\hline 18 & 1750 & 1881 & 15 & 93 & 175 & 90 \\
\hline 19 & 1790 & 1894 & 13 & 95 & 175 & 120 \\
\hline$*$ According numbering presented in Fig. 4 and Table 3 & \\
\hline
\end{tabular}

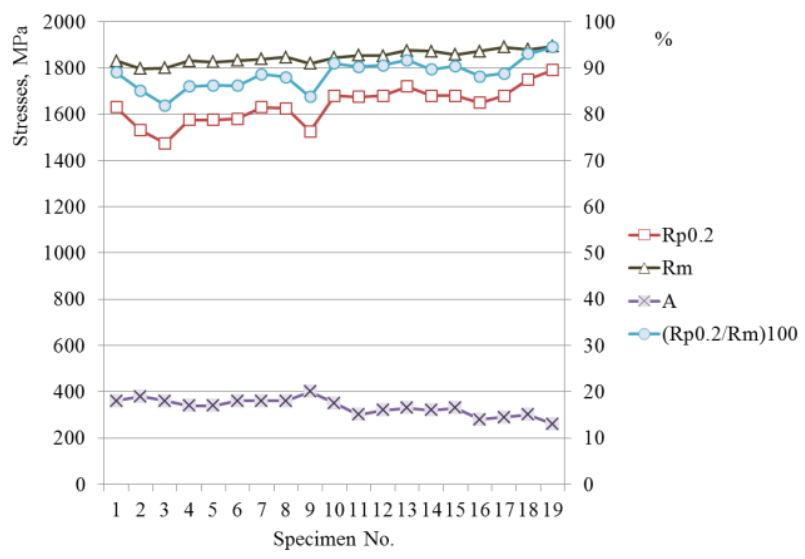

Fig. 11 Mechanical properties of steel wires tempered at different temperatures heating for various durations (group B, Table 5)
Obtained ultimate strength and calculated offset $0.2 \%$ yield strength allowed selection of optimal heat treatment regime for hypereutectoid steel springs.

\section{Conclusions and recommendations}

1. Examination of spring steel microstructure revealed sufficiently high quality of material. The index of non-metallic inclusions was determined to be $i=0.5$ (the lowest index for globular oxides) according standard ISO 4967. Decarburization of the surface was found in one specimen among six ones and did not exceed the permissible limits.

2. Temperature test performed for specimens tempered in the industrial furnace showed that the springs arranged in two pallets did not reach the set temperature of $300{ }^{\circ} \mathrm{C}$ except the small part of them piled near the right wall of the furnace chamber. The average temperature was reached between $210-230^{\circ} \mathrm{C}$.

3. Tensile test of specimens tempered at different temperatures for various durations showed that the best mechanical properties could be achieved when tempering regime is $250-275^{\circ} \mathrm{C}$ for $60-90$ minutes.

4. For getting better mechanical properties the number of springs piled in pallets and heated in industrial furnace should be decreased allowing easier mixing of air inside the furnace.

\section{References}

1. Manual on structural materials. 2005. Ed. by Arzamasov, B. N., Solovjova, T. V.-Moscow: press MGTU of Bauman. 637p (in Russian).

2. Pavaras, A.; Žvinys, J. 1995. Manual. Steels.-Kaunas: Technologija. 415p (in Lithuanian).

3. Werkstoffkunde Stahl. Band 2. 1985. Ed. By W. Jänicke and Mitarb.-Springer-Verlag Berlin-Heidelberg-New York-Tokyo, Verlag Stahleisen, Dusseldorf. 398p (in Russian).

4. Houdremont, E. 1966. Special steels. Vol.1.-Moscow: Metallurgy. 736p (in Russian).

5. Bargujer, S. S.; Suri, N. M.; Belokar, R. M. 2015. Pearlitic steel wire: High carbon steel based natural nanomaterial by lead patenting process, Materials Today: Proceedings 3: 1553-1562. http://dx.doi:10.1016/j.matpr.2016.04.042.

6. Borchers, Ch.; Kirchheim, R. 2016. Cold-drawn pearlitic steel wires, Progress in Materials Science 82: 405-444. http://dx.doi.org/10.1016/j.pmatsci.2016.06.001.

7. Yamada, Y. (chief Ed.) 2007. Materials for Springs. Translated from the Japanese original edition, published by JSSE. Berlin Heidelberg: Springer-Verlag. 377p.

8. Murakami, Y. 2002. Metal Fatigue: Effects of Small Defects and Non-metallic Inclusions.-Oxford: Elsevier Science Ltd. 369p.

9. Lambrighs, K.; Verpoest, I.; Verlinden, B.; Wevers, M. 2010. Influence of non-metallic inclusions on the fatigue properties of heavily cold drawn steel wires, Procedia Engineering 2: 173-181. http://dx.doi:10.1016/j.proeng.2010.03.019.

10. EN 10270-1:2011. Steel wire for mechanical springs Part 1: Patented cold drawn unalloyed spring steel wire. $25 \mathrm{p}$. 
11.EN ISO 16120-1:2011. Non-alloy steel wire rod for conversion to wire - Part 1: General requirements (ISO 16120-1:2011). 21p.

12. EN ISO 16120-2:2011. Non-alloy steel wire rod for conversion to wire - Part 2: Specific requirements for general-purpose wire rod (ISO 16120-2:2011). 7p.

13. ISO 4967:2013. Steel - Determination of content of nonmetallic inclusions - Micrographic method using standard diagrams. 39p.

14. Cruzado, A.; Leen, S.B.; Urchegui, M.A.; Gómez, X. 2013. Finite element simulation of fretting wear and fatigue in thin steel wires, International Journal of Fatigue 55: 7-21. http://dx.doi.org/10.1016/j.ijfatigue.2013.04.025.

15. Takahashi, J.; Kosaka, M.; Kawakami, K.; Tarui, T. 2012. Change in carbon state by low-temperature aging in heavily drawn pearlitic steel wires, Acta Materialia 60: 387-395. http://dx.doi:10.1016/j.actamat.2011.09.014.

16. Zhang, X.; Hansen, N.; Godfrey, A.; Huang, X. 2016. Dislocation-based plasticity and strengthening mechanisms in sub-20 nm lamellar structures in pearlitic steel wire, Acta Materialia 114: 176-183. http://dx.doi.org/10.1016/j.actamat.2016.04.040.

17. Joung, S. W.; Kang, U. G.; Hong, S. P.; Kim, Y. W.; Nam, W. J. 2013. Aging behavior and delamination in cold drawn and post-deformation annealed hypereutectoid steel wires, Materials Science \& Engineering A 586: 171-177. http://dx.doi.org/10.1016/j.msea.2013.07.095.

18. Yilimaz, M. 2006. Failures during the production and usage of steel wires, Journal of Materials Processing Technology 171: 232-239. http://dx.doi:10.1016/j.jmatprotec.2005.07.007.

19. Baek, H. M.; Hwang, S. K.; Joo, H. S.; Im, Y.-T.; Son, I.-H.; Bae, Ch. M. 2014. The effect of non-circular drawing sequence on delamination characteristics of pearlitic steel wire, Materials and Design 62: 137-148. http://dx.doi.org/10.1016/j.matdes.2014.05.014.

20. Das, S.; Mathur, J.; Bhattacharyya, T.; Bhattacharyya S. 2013. Failure analysis of steel wire of grade LRPC during drawing process, Engineering Failure Analysis 27: 333-339.

http://dx.doi:10.1016/j.engfailanal.2012.07.012.

21. Goldshtein, M. I.; Grachev, S. V.; Veksler, J. G. 1999. Special steels.-Moscow: MISIS, 408p.
R. Kandrotaitè Janutienè

\section{INVESTIGATION OF FRACTURE OF CARBON STEEL SPRINGS USED FOR FURNITURE APPLICATION}

$\mathrm{S}$ u m m a r y

The article deals with the investigation of fracture reasons of zigzag springs made from patented and tempered hypereutectoid steel wires. Microscopy analysis was performed for identification of quality of springs' material. It was specified that index $i$ of non-metallic inclusions was the lowest according standard EN 10270-1:2011, i.e. $i=0.5$ and surface defects such as decarburization and roughness examining twelve occasionally collected samples did not exceed the permissible limits. A number of wire rods with cleaned surface from phosphate coating were tempered: 1) in industrial furnace together with spring pallets, 2) in laboratory furnace with welded thermocouples for precise temperature determination. Comparison of colours of oxides films revealed that during tempering of spring pallets in industrial furnace they did not reach the required temperature of $300^{\circ} \mathrm{C}$. The average of temperature inside the chamber of industrial furnace reached just $200-240^{\circ} \mathrm{C}$. The tensile test and following determination of mechanical properties of steel wires tempered at different temperatures heating for various durations allowed selection of the optimal regime of heat treatment of hypereutectoid steel springs.

Keywords: zigzag wire, spring, pearlitic steel, microstructure, patenting, tempering.

Received July 04, 2016 Accepted September 28, 2016 